\title{
Durability and Protection of Timber Structures in Marine Environments in Europe: An Overview
}

\author{
Andreas Treu, ${ }^{a}$ Katrin Zimmer, ${ }^{a}$ Christian Brischke, ${ }^{b}$ Erik Larnøy, ${ }^{a}$ Lone Ross \\ Gobakken, ${ }^{\mathrm{a}}$ Foued Aloui, ${ }^{\mathrm{c}}$ Simon M. Cragg, ${ }^{\mathrm{d}}$ Per-Otto Flæte, ${ }^{\mathrm{e}}$ Miha Humar, ${ }^{\mathrm{f}}$ \\ Mats Westin, ${ }^{\mathrm{g}}$ Luisa Borges, ${ }^{\mathrm{h}}$ and John Williams ${ }^{\mathrm{i}}$
}

\begin{abstract}
Timber structures in marine applications are often exposed to severe degradation conditions caused by mechanical loads and wood-degrading organisms. This paper presents the use of timber in marine environments in Europe from a wood protection perspective. It discusses the use of wood in coastline protection and archeological marine wood, reviews the marine borer taxa in European waters, and gives an overview of potential solutions for protection of timber in marine environments. Information was compiled from the most relevant literature sources with an emphasis on new wood protection methods; the need for research and potential solutions are discussed. Traditionally, timber has been extensively utilized in a variety of marine applications. Although there is a strong need for developing new protection systems for timber in marine applications, the research in this field has been scarce for many years. New attempts to protect timber used in marine environments in Europe have mainly focused on wood modification and the use of mechanical barriers to prevent colonization of marine wood borers. The importance of understanding the mechanisms of settlement, migration, boring, and digestion of the degrading organisms is key for developing effective systems for protecting timber in marine environments.
\end{abstract}

Keywords: Marine wood borers; Use Class 5; Coastline protection; Limnoria spp.; Teredinids; Wood protection

Contact information: a: Norwegian Institute of Bioeconomy Research, Pb. 115, 1431, Ås, Norway; b: University of Goettingen, Wood Biology and Wood Products, Buesgenweg 4, 37077 Goettingen, Germany; c: Institut Sylvo-Pastoral de Tabarka, Département de Protection et Développement des Ressources et des Espaces Agro-Forestiers, BP 345 Tabarka, 8110, Tunisia; d: University of Portsmouth, Institute of Marine Sciences, Ferry Road, Portsmouth PO4 9LY, United-Kingdom; e: Norwegian Institute of Wood Technology, Forskningsveien 3B, 0314 Oslo, Norway; f: University of Ljubljana, Biotechnical Faculty, Department of Wood Science and Technology Jamnikarjeva 101, SI-1000 Ljubljana, Slovenia; g: RISE Research Institutes of Sweden, P.O. Box 5604, 11486 Stockholm, Sweden; h: L3 Scientific Solutions, Runder Berg 7e, 21502 Geesthacht, Germany; i: RSK, 18 Frogmore Road, Hemel Hempstead, Hertfordshire, HP3 9RT, UK; *Corresponding author: andreas.treu@nibio.no

\section{INTRODUCTION}

\section{Timber Structures in the Marine Environment}

Timber structures in marine applications are exposed to harsh environments in the intertidal and subtidal zones (Tsinker 1995). These diverse environments include a wide range of deteriorating organisms such as bacteria, decay fungi, and marine wood borers (Oevering et al. 2001). In addition to the resistance to wood-degrading organisms, high mechanical resistance of marine structures, in particular on the shoreline, is required due to high mechanical loads caused by the recurrent impact of waves and shingles, sand, ice,

Treu et al. (2019). "Timber in marine environments," BioResources 14(4), 10161-10184. 10161 
and other solid fragments transported by the waves, wind, and tide. Groynes and revetments represent two of the most challenging applications for wood materials, because they need to withstand both high mechanical loads and the attack of biological organisms. Abrasion resistance is needed as well, which is typically achieved by using dense tropical hardwoods. Timber in the marine environment is, in contrast to other construction materials such as concrete and steel, only insignificantly affected by the salt content (Cragg 1996). In spite of its accessibility to deteriorating organisms, timber is an attractive construction material for decision makers for marine environments, not the least due to its renewable character, resilience, favorable strength to weight ratio, but also flexibility in fabrication and repair (Williams et al. 2005).

\section{The use of timber in port constructions and jetties}

Wharves and jetties are often constructed of concrete and steel, which are capable of withstanding higher loads imposed by contemporary shipping. Although smaller structures may still employ timber, concrete will keep its importance for port constructions and remain the dominant material in the future (Alexander and Nganga 2016). However, marine structures made from steel or reinforced concrete are greatly affected by chloride ion, which leads to corrosion (Sosa et al. 2011). In marina design, where the structures often are designed to float, timber is still preferred for its aesthetics, pedestrian comfort, and ease of repair (Williams et al. 2005). These timber structures mainly need to withstand the attack of biological organisms, unlike groynes and revetments.

\section{The legal situation concerning wood preservatives in Europe}

The use of biocides and preservative-treated wood in Europe is mainly regulated by the Biocidal Products Regulation (BPR) (EU Regulation 528/2012 2012) and the Construction Products Regulation (CPR) (EU Regulation 305/2011 2011). The BPR regulates the biocides on the market and harmonizes these products for the European market. This includes both the active substances and treated products. The CPR only applies to specific product groups intended for construction that a current European Harmonized Standard exists. In addition, labels are issued regarding the quality and the performance of preservative-treated timber for the different European countries (Kutnik et al. 2017; Stephan et al. 2017). Referring to current standards, there are no preservatives used in Europe that are approved for use in the Use Class 5 (marine) category (EN 335 2013).

\section{Wood protection in Use Class 5}

Different service situations or environments for wood products are expressed as use classes from class one to five in the respective European standard (EN 335 2013). These use classes define the application of wood from indoor to outdoor applications, such as wood and wood-based products not exposed to the weather and wetting (Use class 1), under cover and not exposed to the weather, but with occasional wetting (Use class 2), above ground and exposed to weather (Use class 3), in direct contact with ground and/or fresh water (Use class 4), and permanently or regularly submerged in salt water (Use class 5). Wood protection systems with CCA (copper, chromium, arsenic), creosote, or double impregnations of both CCA and creosote are widely used around the world in the European Use Class 5/Australian Hazard Class 6 (AS1604.1 2012; SANS 10005 2016; AWPA 2017). However, due to the harsh environment in marine applications, retention requirements in Europe for CCA in Use Class $5\left(40 \mathrm{~kg} / \mathrm{m}^{3}\right)$ were 10 times higher than in Use Class 3 
applications $\left(4.0 \mathrm{~kg} / \mathrm{m}^{3}\right.$, situation where wood is exposed to weather). A slightly lower difference was prescribed for creosote $\left(128 \mathrm{~kg} / \mathrm{m}^{3}\right.$ in Use Class 3 , and $400 \mathrm{~kg} / \mathrm{m}^{3}$ in Use Class 5 applications) (Wilkinson 1979). However, the highly effective preservative CCA has been banned in Europe since 2004, and the industrial use of creosote faces tighter restrictions since 2013, while consumer use of creosote has been banned since 2003 due to the ecotoxicity of these substances and for being harmful to human health. Today, no wood preservative is approved for application in seawater in Europe. Humar et al. (2013) showed that in the field trials in the Northern Adriatic Sea, the performance of biocide-treated wood samples improved with increasing concentration of the biocide. The Alkaline Copper Quaternary (ACQ)-based wood preservatives were assessed at this study site. To ensure a similar protective efficacy for copper-treated wood, as previously reported for CCA-treated wood, high retentions of active ingredients were shown to be required. A five-year study in port Koper in Slovenia indicated that wood should retain approximately $70 \mathrm{~kg} / \mathrm{m}^{3}$ of ACQ-based copper preservatives after impregnation to enable sufficient durability. This concentration is six times higher than the retention approved for Use Class 3 applications. However, such high retentions lead to rather high concentrations of active ingredients in the leachates at least during the beginning of the exposure. Hence, it is very unlikely that these ACQ-based preservatives will be approved due to eco-toxicological regulations. ACQ-based preservatives, are discussed for their use in marine environments and underwent first monitoring studies, e.g., at the German Baltic Sea shore (Hellkamp 2012). It is unlikely that these protection measures withstand harsh coastal conditions due to abrasion, which could easily wear away the treated outer zones of the timber.

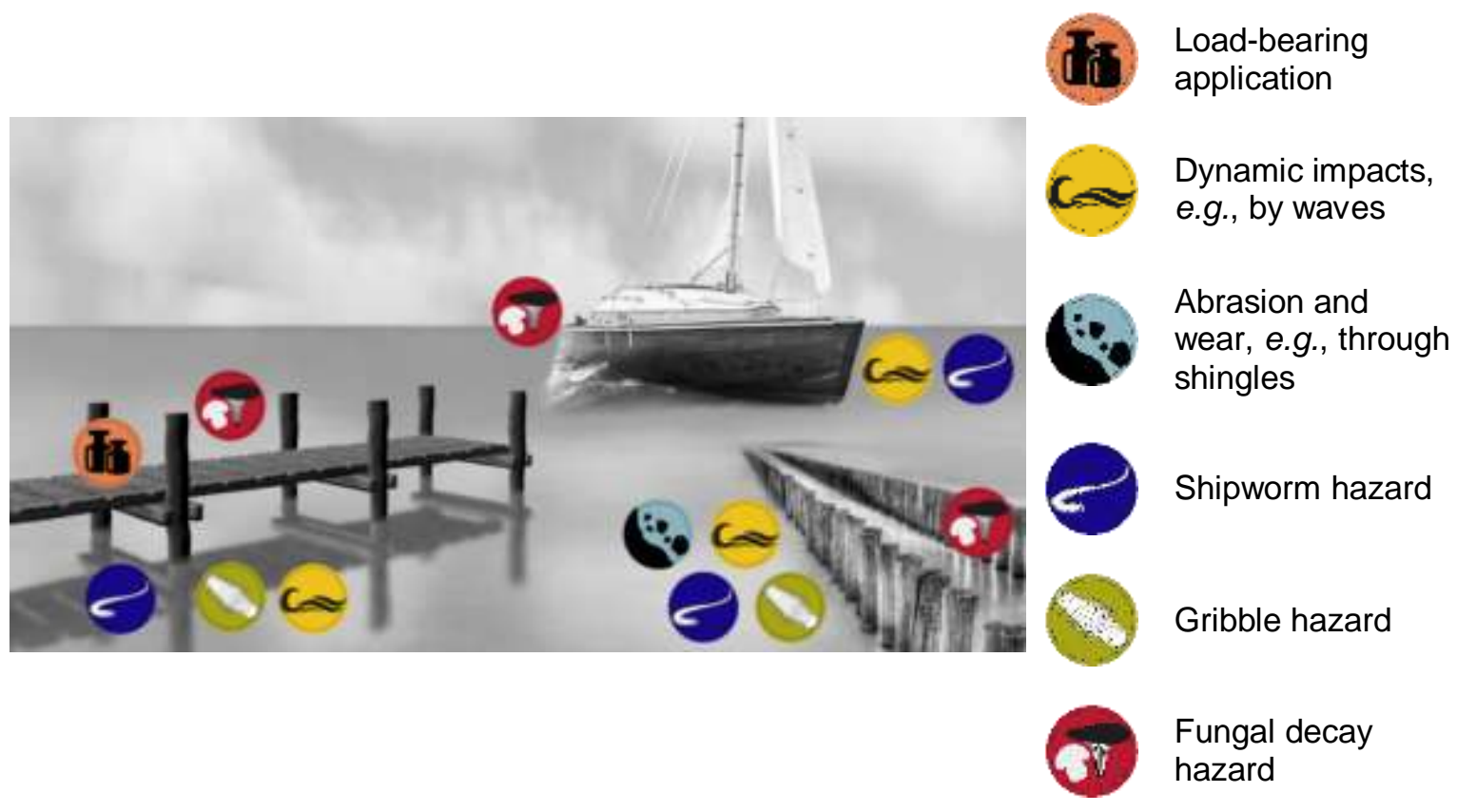

Fig. 1. Portfolio of abiotic and biotic hazards relevant for marine structures (Illustration: Treu et al. 2018)

\section{Requirements for Material Properties of Timber in the marine environment}

In a survey on the perception of material attributes for timber serving in the marine environment, such as timber pilings or groyne planking in the UK, the respondents identified the resistance to marine wood borers as the most important material property,

Treu et al. (2019). "Timber in marine environments," BioResources 14(4), 10161-10184. 10163 
followed by strength, resistance to impact, abrasion, and fouling by marine organisms (Williams et al. 2005). The desired material properties of timber for use in the marine and fluvial environments can be summarized as being: high density, to withstand the scouring action of the waves; strong, especially in bending; high stiffness to withstand impact; high durability, against fungal attack and against marine wood borers; treatable, in case of nonrefractory wood species with low natural durability; and large in dimension, necessary if construction is in areas with large differences in water level due to tide. The different biotic and abiotic factors are summarized in Fig. 1.

\section{Aim of Overview}

This paper presents: 1) the use of timber in the marine environment in Europe from a wood protection perspective, 2) a compilation of the most relevant literature with an emphasis on new wood protection methods, and 3) potential solutions and the need for future research that can contribute to the durable use of wood in marine applications.

\section{MARINE ORGANISMS ATTACKING TIMBER}

Wood borers consume submerged wood in the sea and fulfil an important ecological role in the turnover of organic material. Untreated anthropogenic wood structures are attacked in the same manner as natural wood debris. The most important and accurate work in terms of comprehensive and systematic overview of wood borers, Limnoriidae and Teredinidae, was conducted in the 1950s and 1960s, respectively (Menzies 1957; Turner 1966). Marine wood borers include Bivalvia (Teredinidae and Xylophagaidae), Isopoda (Limnoriidae and Sphaeromatidae), and Amphipoda (Cheluridae). In Europe most wood-boring bivalves belong to the Teredinidae, but species of the Xylophagaidae, such as Xylophaga dorsalis, also have been reported as present near the sea bed in Europe (Santhakumaran and Sneli 1978). Attack by teredinids is difficult to detect with the naked eye, but a magnifying glass can more easily display entrance holes of larvae. The degree of attack is usually analyzed by x-ray, when non-destructive evaluation is required, such as computer-aided tomography (Charles et al. 2018), but can also be investigated by density measurements or strength determination as well as wood sample preparation and borer species identification (Turner 1966).

The European wood-boring Crustacea belong to the Limnoriidae and Cheluridae families. Their attack pattern is shaped by their tunneling activities on the wood surface and is usually easier to detect with the naked eye compared with shipworm attack. In combination with wave action in the tidal zone, wooden piles will show an hour-glass shape. More recent reviews on potential attacking wood borers in the marine environment is given for Limnoriidae by Cookson (1990) and Cragg (2003) and for Teredinidae by Distel (2003), and Voight (2015), where the authors provide a current state of knowledge about biogeography, competition and predation among wood borers and the role of bacterial endosymbionts. In addition, Table 1 gives an overview of wood borer species and their occurrence in European waters.

In addition to wood borers, obligate wood-degrading marine fungi are able to degrade wood. These fungi occur solely in saline waters or close to river mouths. Furthermore, facultative marine fungi, which are usually found in freshwater and terrestrial environments, are also able to grow in the saline marine environment. Their ability to degrade lignocellulose make them important organisms that need to be taken into account

Treu et al. (2019). "Timber in marine environments," BioResources 14(4), 10161-10184. 10164 
when using timber in seawater (Hyde et al. 1998). Bacterial and soft-rot decay also occur on wood in marine applications and can cause surface erosion, degradation, and deterioration (Daniel and Nilsson 1998). Other fouling organisms, e.g., barnacles, which can attach to the wood and other surfaces, are especially feared in relation to the protection of boat hulls (Wiegemann 2005).

Table 1. Marine Wood-boring Species in Europe and Their Salinity and Temperature Requirements

\begin{tabular}{|c|c|c|c|c|c|}
\hline Family & Species & $\begin{array}{l}\text { Salinity, } \\
\text { SSS } \\
\text { (PSU) }\end{array}$ & $\begin{array}{c}\text { Temperature } \\
\text { SST }\left({ }^{\circ} \mathrm{C}\right)\end{array}$ & Sampling site & Reference \\
\hline \multirow[t]{5}{*}{ Teredinidae } & $\begin{array}{l}\text { Teredo navalis } \\
\text { (Linnaeus) }\end{array}$ & 7 to 35 & 0 to 30 & $\begin{array}{c}\text { Kristineberg } \\
\text { Marine } \\
\text { Biological } \\
\text { Station-Sweden; } \\
\text { Roskilde, } \\
\text { Denmark; } \\
\text { Foresterei } \\
\text { Timbrook, } \\
\text { Germany; Kiel, } \\
\text { Germany; } \\
\text { Haren, } \\
\text { Netherlands; } \\
\text { Yerseke, } \\
\text { Netherlands; } \\
\text { Berder, France; } \\
\text { Golfe du } \\
\text { Morbihan, } \\
\text { France; } \\
\text { Baie de Villaine, } \\
\text { France; } \\
\text { Toulindac, } \\
\text { France; Rovinj, } \\
\text { Croatia; Amasra, } \\
\text { Turkey; Mersin, } \\
\text { Turkey }\end{array}$ & \multirow[t]{5}{*}{$\begin{array}{l}\text { Borges et al. } \\
\quad(2014 b)\end{array}$} \\
\hline & $\begin{array}{c}\text { Psiloteredo } \\
\text { megotara } \\
\text { (Hanley) }\end{array}$ & 27 to 37 & 1 to 25 & $\begin{array}{l}\text { Trondheim } \\
\text { Fjord, Norway }\end{array}$ & \\
\hline & $\begin{array}{c}\text { Nototeredo } \\
\text { norvagica } \\
\text { (Spengler) }\end{array}$ & 17 to 39 & 2 to 39 & $\begin{array}{c}\text { Trondheim, } \\
\text { Norway; } \\
\text { Toulindac, } \\
\text { France; } \\
\text { Berder, France; } \\
\text { Penerf, France; } \\
\text { Banyuls-sur- } \\
\text { Mer, France; } \\
\text { Mersin Bay, } \\
\text { Turkey }\end{array}$ & \\
\hline & $\begin{array}{c}\text { Bankia carinata } \\
\text { (Gray) }\end{array}$ & 10 to 30 & 35 to 40 & $\begin{array}{l}\text { Rovinj, Croatia; } \\
\text { Mersin Bay- } \\
\text { Turkey }\end{array}$ & \\
\hline & $\begin{array}{c}\text { Lyrodus } \\
\text { pedicellatus } \\
\text { (Quatrefages) }\end{array}$ & 33 to 37 & 7 to 24 & $\begin{array}{l}\text { Portsmouth, } \\
\text { England; Golfe } \\
\text { du Morbihan, }\end{array}$ & \\
\hline
\end{tabular}




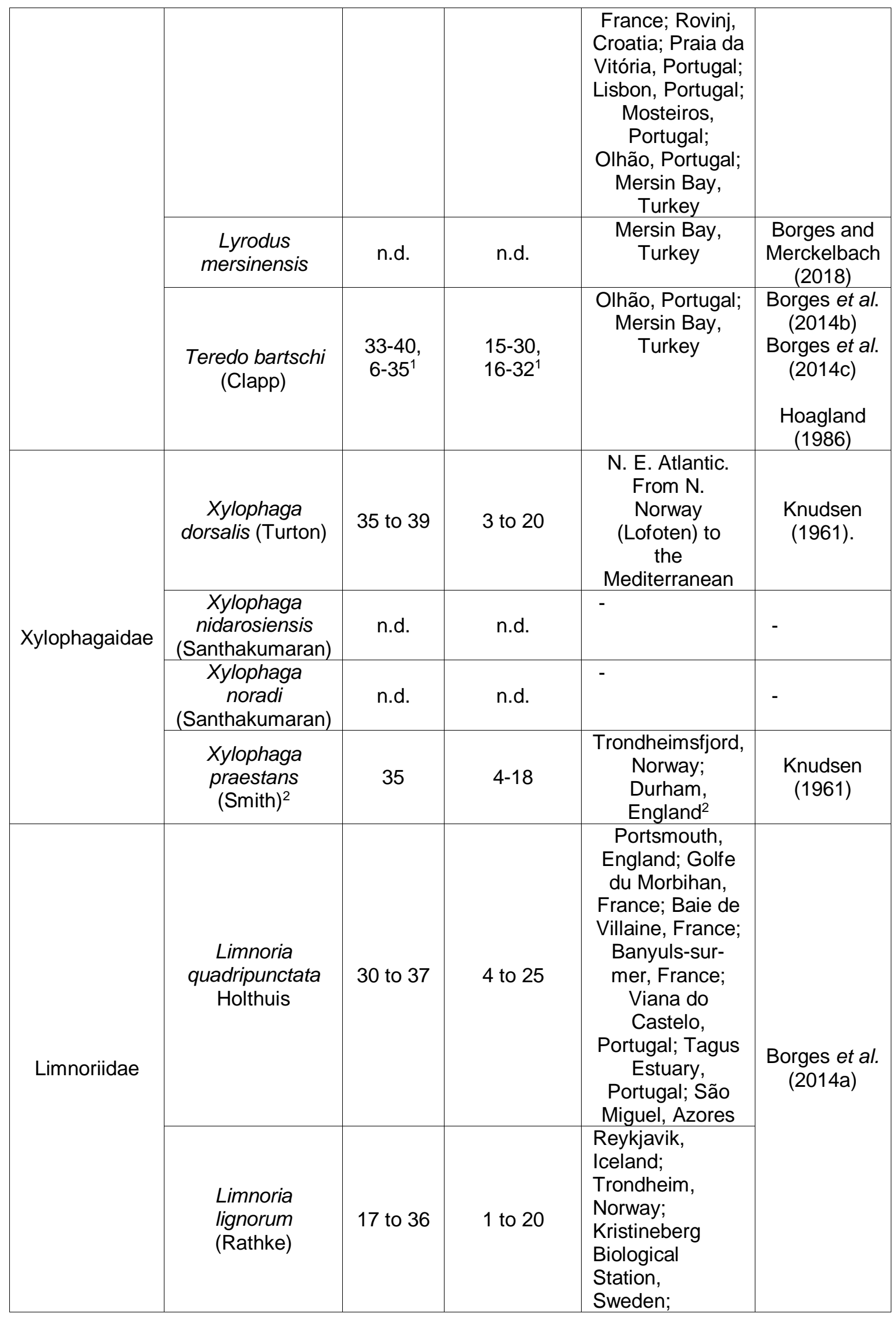




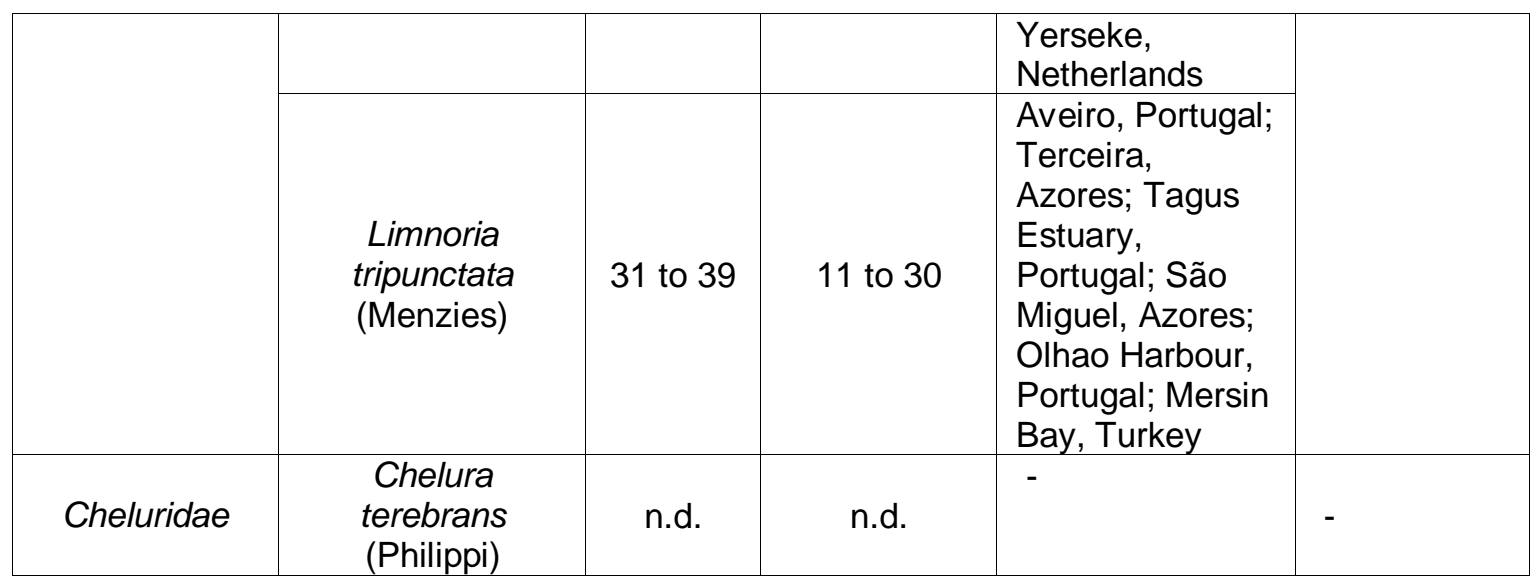

Note: The different species were found either in wood panels or in fixed wooden structures in the described areas usually at a depth of 2-3 meters; n.d. = no data; SSS = Sea Surface Salinity; SST = Sea Surface Temperature; ${ }^{1}$ data reported for lavae from New Jersey, USA; ${ }^{2}$ usually found in greater depths.

\section{Distribution of Wood borers}

Comprehensive studies on the biogeography of both wood-boring crustaceans (Limnoriidae) and bivalve wood borers (Teredinidae) have been performed in European coastal waters. These studies showed the diversity of established species and their past and recent distribution (Borges et al. 2014a,b). It is evident from studies on wood boring limnoriid species that Limnoria quadripunctata and L. tripunctata have extended their range in European waters, while the distribution of L. lignorum appears to have declined (Borges et al. 2014a). Studies on the occurrence of teredinids in European waters show that some species extend, contract, or compete in the same distribution range which each other. Depending mostly on their high tolerance to water temperature and salinity, the wood borer species Teredo navalis and Nototeredo norvagica show a wide distribution area in Europe. However, the reproductive patterns, in particular the release of short-term or long-term living larvae (larviparous) in comparison with oviparous species, which lay eggs with little or no other embryonic development, can be responsible for a competitive advantage (Borges et al. 2014b). The distribution of Teredo navalis and Lyrodus pedicellatus in European waters should be monitored due to their destructive capacity, as well as the spreading of alien species such as Teredo bartschi and Teredothryra dominicensis (Borges et al. 2014c). Monitoring the activity of wood borers is important and needs to be continued to predict the service life of wood structures in marine environments.

\section{Wood borers in Northern coastal waters}

The distribution of shipworms is not limited to warmer geographical areas. They can occur in seawater temperatures ranging from the Mediterranean areas to the Arctic Circle. The most common coldwater shipworm species along the west coast of Norway is Psiloteredo megotara, which is found even north of Finnmark (Knudsen 1974). The spread of the different species along the coast of Norway is otherwise not documented because most surveys have been based on limited areas along the coast. However, it can be noted that Nototeredo norvagica is found along the coast of north and western Norway (Nair 1962). Santhakumaran and Sneli (1984) found Psiloteredo megotara, Xylophaga dorsalis, Xylophaga praestans, Xylophaga nidarosiensis, and Xylophaga noradi in the Trondheimsfjord. Dons (1948) stated that in Trøndelag, N. norvagica occurs especially in the archipelago, while Psiloteredo megotara is dominant in the fjord. According to Dons

Treu et al. (2019). "Timber in marine environments," BioResources 14(4), 10161-10184. 10167 
(1948), Teredo navalis is not established north of Bergen. A comprehensive study on the different fouling and wood-boring organisms in the fjord of Trondheim in western Norway was performed by Santhakumaran and Sneli $(1978,1984)$. Since then, no research has been published on wood protection in marine environments in Norway.

Wood borers along the Swedish coast have been extensively analyzed during the last decade. Despite an increase in surface sea water temperature, no significant increase in abundance of Teredo navalis at several test sites at the Swedish west coast was observed. A decreased abundance of teredinids towards the Southern part of Sweden's West coast was found. The hypothesis of shipworms having expanded their range into the Baltic Sea could not be proven (Appelqvist et al. 2014; Appelqvist 2015).

\section{CHANGING CONDITIONS IN MARINE APPLICATIONS}

\section{Climate Change and Sea Level Rise}

A recent study by Nerem et al. (2018) on climate change-driven sea level rise predicts an accelerating rate, which highlights the significance of the problem and the importance for coastal protection. The reported sea level rise in combination with extreme weather events will lead to increasing costs for coastal protection. It is believed that England and Wales invest around $£ 500$ million per year in flood and coastal defense engineering (Simm and Masters 2003). Newer figures from the Environment Agency in the United Kingdom reports bids for contract works with an estimated total value of $£ 220$ million (Environmental Agency 2018).

A report on sea level change in Norway predicts a fall in relative sea level in the Oslofjord inlet and in the middle of Norway, but a rise in relative sea level for the Norwegian coast in the South and West and for the northernmost tide gauges (Simpson et al. 2015). Correcting for the glacial isostatic adjustment (GIA), the sea surface height rates are positive and close to the global average rates.

\section{Coastline Protection}

Coastal erosion is an increasing problem that is influenced by accelerated sea level rise (Leatherman et al. 2000), changes in sediment supplies, storms, river delta subsidence, and human impact (Eurosion 2002). An overview of coastal erosion patterns in Europe is given in Fig. 2. There are a number of forms of coastal defenses where timber can be included, such as seawalls, revetments, breakwaters, groynes, and dune fencing. Timber is a technically versatile material since it offers a balance between strength, size, durability, workability, and buildability (Crossman and Simm 2004). A coastal protection system consists of a combination of beach and backshore elements such as cliffs, beaches, dunes, and/or artificial defenses that contribute to flood protection and coastal erosion prevention (Hudson et al. 2015). A gradual change from hard protection structures, such as groynes, revetments, offshore breakwaters and seawalls, to soft coastal defense techniques, such as artificial nourishment of beach areas, has been observed over the last 60 years. However, such techniques are neither easy to sustain nor well established and vary widely throughout the different European countries (Hanson et al. 2002).

One method for hard coastline protection is the use of groynes, which must withstand heavy wave impact and are exposed to longshore drift of shingle or sand. However, timber has an advantageous strength to weight ratio and is versatile and adaptable in design. Timber structures are more easily repaired or extended than concrete

Treu et al. (2019). "Timber in marine environments," BioResources 14(4), 10161-10184. 10168 
structures. Repair on woodpiles for marine applications has been demonstrated by using fiber-reinforced polymer and could fully restore the bending strength of a damaged woodpile. (Lopez-Anido et al. 2003).

The increase of coastal erosion is associated with an increase in costs. The following key cost components may need to be considered to estimate the total costs of coastal protection: procurement and design costs, capital construction costs, operation and maintenance costs, monitoring costs, and replacement or decommissioning costs (Hudson et al. 2015). For example, timber revetments could be cheaper in capital costs but higher in maintenance costs than rock revetments. Overall, the use of timber is more attractive for the construction of groynes compared with the use of rocks, when costs and environmental issues are considered. When compared to other materials for the construction of piles for groynes, recycled wood is favored due to reasonable service life and low transport costs, but mainly due to ecopoints, a system that assesses wide environmental impacts, material and transport options (Masters 2001; Crossman and Simm 2004).

All European countries that have a coastline are affected by coastal erosion. Altogether, $20 \%$ of the coastline in Europe faced serious impacts in 2004, with a large area of retreating zones. Timber can be, or is already used, in the 4,700 km of artificially stabilized coastlines (Salman et al. 2004).

A study on global coastal protection considers an investment in protection of the high-populated coastal areas as economically robust, which means these areas would save money investing in protection rather than not protecting their coastline (Lincke and Hinkel 2018).

\section{Changes in the Abundance and Distribution of Wood Borers}

Changes in the requirements on timber applied in the marine environment are anticipated not only because of sea level rise and extreme weather events, which threaten the safety of coastlines, but also because of the change in seawater temperature, salinity, and the import of foreign wood-deteriorating species. The increase in salinity due to global warming could enable marine wood borer mollusks of the families Teredinidae and Xylophagaidae, to invade other areas, e.g. the waters of Russia and adjacent marine areas where these changes of environmental factors would promote an invasion of wood borers (Iljin 2010). Only a few of the numerous environmental factors are limiting the colonization of new regions by these organisms. These factors mainly include the abiotic ones, such as temperature and water salinity, as well as ice conditions.

While no evidence of the invasion of the Baltic Sea by teredinid recruits was found on the Swedish coast (Appelqvist et al. 2014), it is reported that shipworm is spreading within the Southern part of the Baltic Sea, leading to severe problems and economic damages in Denmark, Germany, Poland, and Southern Sweden (Sordyl et al. 1998; Borges et al. 2014b; Lippert et al. 2017). While the abundance of Teredo navalis was positively correlated to the surface water salinity, no positive correlation to temperature could be shown. Climate models anticipating a decrease in salinity would affect negatively the abundance of T. navalis, in the Baltic sea (Appelkvist et al 2014). Tuente et al. (2002) reported the occurrence of Teredo navalis in the harbors of Bremerhaven at the shores of the North Sea in Northern Germany for the first time in 2002.

A study of $T$. navalis in the southwestern Baltic Sea showed an increased abundance with increased temperatures and salinity. However, high variation in abundance also depending on the evaluation year, made it difficult to explain the factors controlling the settlement. The distribution of this shipworm species could be slightly changed towards

Treu et al. (2019). "Timber in marine environments," BioResources 14(4), 10161-10184. 10169 
the Mecklenburg-Western Pomeranian Baltic Sea coast, where a dramatic increase in the amount of damage in timber structures was observed (Lippert et al. 2017).

Economic damage on timber structures caused by marine wood borers accounts for many billion $€$ per year (Saathoff et al. 2010). During the last mass occurrence of Teredo spp. at the German Baltic Sea coastline, groynes valued at $€ 12.8$ million were destroyed in 1993 (State Agency for Agriculture and Environment Middle Mecklenburg 2017). Invasive species have also been found in the Mediterranean Sea, which is of considerable concern if species are tropical because they are particularly destructive and degrade wood more rapidly (Shipway et al. 2014; Borges et al. 2014c). The spreading of shipworm could be avoided by removing wooden structures along the coastlines (Appelqvist et al. 2015). However, this is a counterproductive solution if an increased use of wood is desired. In addition, driftwood is a significant energy source for different organisms in the marine ecosystem and elimination of driftwood is hardly possible nor desirable.

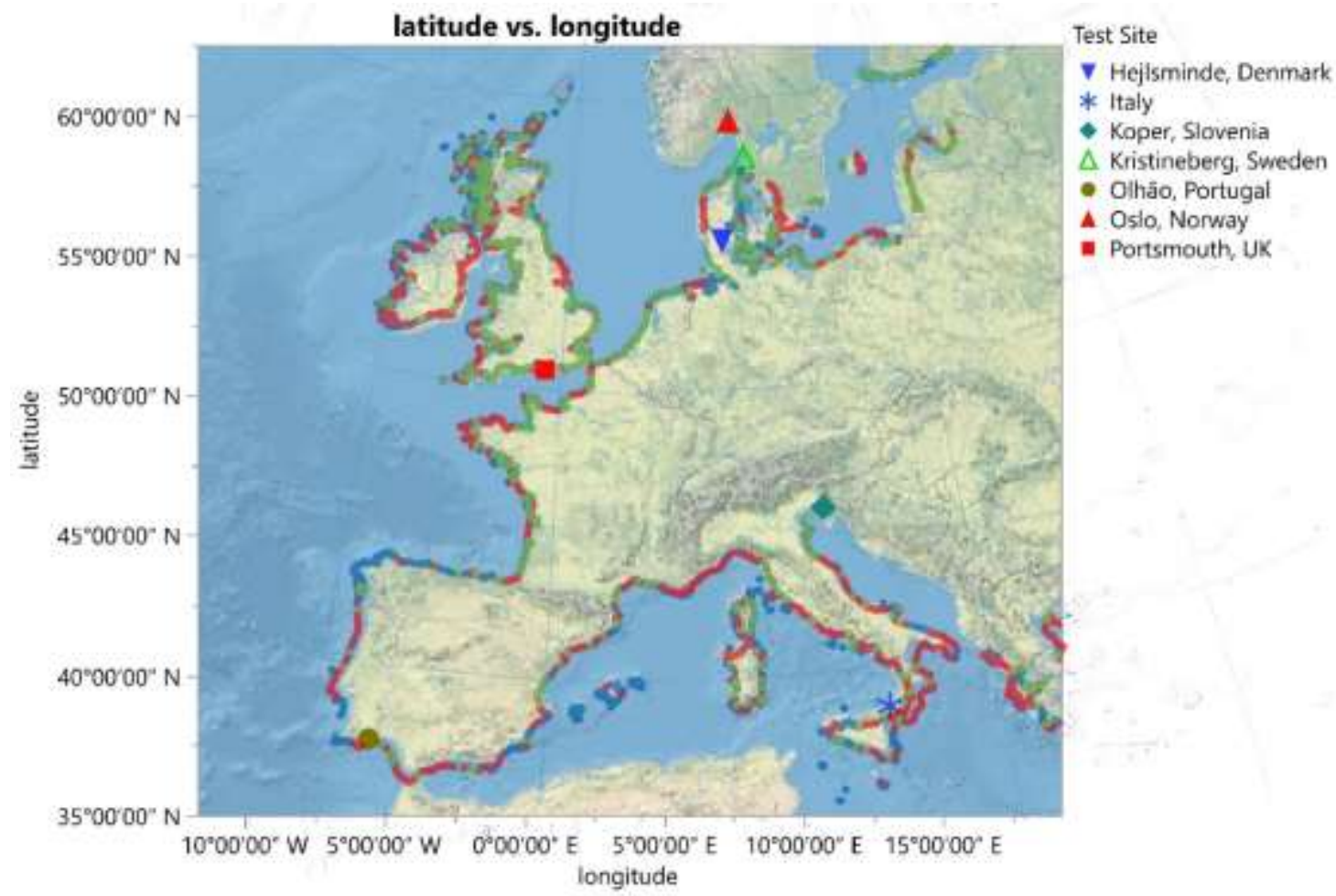

Fig. 2: Permanent marine test sites for wood treatments and overview of coastal erosion patterns in Europe according to the European Environment Agency (2016); (aggradation in green, erosion in red, stable conditions in blue)

\section{RESEARCH ACTIVITY IN RECENT YEARS}

The research done on wood-boring organisms in the marine environment is mostly related to novel solutions for the protection of wood, tropical wood species with high natural durability, the attack on waterlogged archaeological wood, and the abundance and distribution of these organisms on different areas of the world.

\section{Research on Wood Protection and New Solutions}


New attempts to protect wood in the marine environment in Europe focus mainly on wood modification (Klüppel et al. 2014; Lopes et al. 2014; Janus et al. 2018; Klüppel 2018; Westin et al. 2006, 2016). A wood modification protects timber from biological degradation by using non-biocidal mechanisms. Wood treated with 1,3-dimethylol 4,5dihydroxy ethylene urea (DMDHEU), methylated-methylol-melamine resin (MMF), acetic anhydride, or furfuryl alcohol provided resistance to marine wood borers (Klüppel et al. 2014; Westin et al. 2016). However, the currently available wood modification technologies are still essentially niche products that come at a cost, and this restricts their use to higher value products. Some of these new treatment methods, such as thermally modified wood, give a brittle wood material or they only protect the wood material for a short period of time when exposed to the marine environment. In addition to wood preservatives and wood modification systems, protection of timber structures in seawater has been achieved using metals, concrete, plastic, and coatings as physical barriers (Findlay 2013). The performance of physical barriers is limited by corrosion, cracking, or breaking, which will allow marine wood borers access to the timber within. Other treatment solutions that focus on the protection of full-size wooden poles by wrapping geotextiles around them were found to provide sufficient protection against shipworm (Saathoff et al. 2010; Müller 2014). However, geotextiles are believed to allow fungal decay in untreated wood. Furthermore, the wood borer Teredo spp. is even described as a problem in subsea umbilical, which are high-tech cable connections often used by the oil and gas industry in subsea applications (Parkes and Keeble 2016). The authors provide no direct evidence that the destruction in modern cables is due to teredinids. It is more likely that species from the Pholadidae are the responsible organisms. In fact, Xylophaga species are described to be found in the insulation of submarine telegraph cables and feed entirely on plankton (Purchon 1941).

It is imperative to know the mechanisms of settlement, boring, and digestion of the degrading organisms to develop effective ways to protect timber in marine environments. The first settlement of larvae on the wood surface is an important phase of the life cycle of Teredinidae, but very little is known about the cues and processes that promote this settlement. Shipworm larvae are attracted to wood by chemical cues, but only to a limited degree. These chemical cues are described to be effective during or after the attachment of the larvae, or very close to the wood substrate. Therefore, the larval settlement is not entirely random (Toth et al. 2015).

In contrast to the aim of avoiding larval settlement of shipworm larvae, researchers have worked on the optimal recruitment of larvae to substrates for commercially used bivalve species such as pearl oysters (Wassnig and Southgate 2012). This study is an example of how settlement can be promoted by manipulating the substrate. The opposite effect, preventing substrate settlement, could be key to wood protection measures in the future. More research in the field of the marine wood borer settlement will make for a better understanding of the settlement strategies. This gained knowledge will enable the development of new protection systems, which make timber unrecognizable for boring organisms.

Once the wood-boring organisms detect the wood material, they need to attach to the surface. Studies on barnacle attachment demonstrated the diversity of adhesive chemistry within barnacle species (Wiegemann and Watermann 2004; Wiegemann 2005; Wiegemann et al. 2006; Jonker et al. 2015). However, since the knowledge on barnacle attachment is not transferable to wood borer settlement and cues for settlement are species specific, more research could investigate species-dependent wood borer settlement. Further

Treu et al. (2019). "Timber in marine environments," BioResources 14(4), 10161-10184. 10171 
research should result in non-toxic fouling prevention systems for the marine environment. However, new antifouling strategies need to include both the chemical concepts, such as surface energy, and the physical concepts, such as surface roughness and fluid hydrodynamics (Magin et al. 2010).

Several authors (Miller 1924; Board 1970; Roder 1977; Dorgan 2015) comprehensively describe the burrowing and boring methods, as well as how an increase in hardness of wood will contribute negatively to burrowing and boring. However, in forced feeding laboratory tests on Limnoria quadripunctata, this correlation could not be seen when testing a range of wood species (Cragg et al. 2007). The same organism was tested using sodium silicate-treated wood, resulting in leaching of the impregnated, active substance (Serpa 1980). Laboratory trials need to take into account the potential toxic effect of the leachate. The mandibles of $L$. quadripunctata were damaged in a laboratory test on wood samples impregnated with two mineralizing-based solutions, suggesting that abrasiveness and hardness of the wood had been increased (Bowen et al. 2017). Unfortunately, it is not mentioned in the study which kind of mineralizing solutions were used. A potential method worth testing is the treatment of wood with calcium carbonate or barium sulphate to increase the hardness of the outer wood layer and to disguise the wood material for the marine wood borers (Merk et al. 2015, 2016, 2017). These strategies could work in estuaries, port facilities, and sheltered environments. However, they are unlikely to work in coastal situations due to abrasion.

Feeding and digestion of wood by borers has been a research focus in recent years (King et al. 2010; Betcher et al. 2012; Kern et al. 2013; Eriksen et al. 2015; Sabbadin et al. 2018). This is vital information that needs to be utilized in further research on wood protection. Several papers describe the degradation pattern from a marine zoology perspective or the enzymatic degradation related to the biomass utilization aspect (Sabbadin et al. 2018). Minimal research has been focused on understanding these degradation mechanisms. The endosymbiotic bacteria in the gills of shipworm have been proposed to assist the shipworm host in cellulose digestion and have been shown to play a role in nitrogen fixation (Distel et al. 2002; Elshahawi et al. 2013; O'Connor et al. 2014).

A second generation of wood modification that includes optimized modification systems or a combination of treatments, may have the potential for long-term use in the marine environment. Furthermore, these new products could either fulfill a wide range of performance criteria or be tailored for a certain type of application. In addition, research needs to be 'borer species' related and needs to focus on the mechanisms of settlement, boring, and digestion of the degrading organisms.

\section{The Use of Tropical Wood Species in Marine Applications}

Durable tropical wood species have been used for different applications in seawater contact and building of marine structures often stick to a limited number of well-established wood species. There are a number of tropical wood species and lesser-known timbers with comparable resistance to timbers currently used for marine construction (Santhakumaran and Sneli 1978; Rosenbusch et al. 2006; Borges et al. 2008; Sen et al. 2009; Palanti et al. 2015), but they often face difficulties in being accepted by the users. The suppliers of lesser-known species must increase the end user's knowledge of their products (Williams et al. 2005). However, the use of well-established tropical wood species is increasingly diminishing because their production is associated with illegal logging, deforestation, and socio-political problems in the respective origin countries. Evidence of a legal and sustainably managed source is required when importing tropical timber. In addition, the

Treu et al. (2019). "Timber in marine environments," BioResources 14(4), 10161-10184. 10172 
costs for tropical timbers are on average three times higher compared to home-grown Scots pine (Saathoff et al. 2010). Other European wood species, such as black locust (Robinia pseudoacacia), sweet chestnut (Castanea sativa), and English oak (Quercus robur), have been used for groynes but suffered from premature failures. All of the above listed European wood species were completely degraded by wood borers after 6 to 8 months of exposure in Port Koper, Slovenia, by Teredo spp., Lyrodus spp., and Limnoria spp. According to the European standard EN 350 (2016), none of these wood species were classified as resistant against marine wood borers as was none of the European species listed. However, a study performed by Norman (1976) on different Swedish wood species showed that barked aspen roundwood was attacked at a lower rate than debarked roundwood, and the attack occurred only through the cutting edges. However, in a more recent study, debarked aspen was heavily attacked after 4 months in different test sites within the Oslofjord inlet (Treu et al. 2018).

\section{Research on Waterlogged Archaeological Wood}

Extensive research has been conducted on waterlogged archaeological wood in marine and terrestrial environments (Björdal et al. 1999; Blanchette 2000; Christensen et al. 2006). Wood degradation in marine sediments is mainly restricted to bacterial decay due to the absence of oxygen. A study on wood samples exposed at different distances above and below the seabed revealed a complete decomposition of wood exposed above seabed, while increased depth of buried wood samples in the seabed showed decreasing decay (Björdal and Nilsson 2008).

The Swedish wooden warship Vasa, which sank in the harbor of Stockholm in 1628, has been exposed close to the seabed for over 300 years before it was rediscovered in 1956 and salvaged in 1961. After placing the ship in a temporary museum, the hull was sprayed with polyethylene glycol (PEG) until 1979. After a drying period, the ship was moved to the Vasa museum in 1990 for permanent display. Undertaken research on the Vasa ship was related to various conservation issues including measures against chemical, physical, and biological degradation (Sandström et al. 2003; Fors and Sandström 2006; Lindfors et al. 2008). More ship wrecks that have withstood exposure in marine environments for centuries and have been subjected to conservation and related research were the 'Mary Rose' in Portsmouth (Squirrell and Clarke 1987; Mouzouras et al. 1990; Sandström et al. 2005) and the 'Bremen Cog' displayed in Bremerhaven (Hoffmann 2001). Nevertheless, the overall number of well-preserved shipwrecks and other wooden artefacts from the sea is comparatively small due to the harsh environmental conditions and aggressive organisms present.

Research on the waterlogged archaeological wood showed that the extent of remaining cellulose had an influence on the attack by shipworms. Areas in the wood with insufficient cellulose were not attacked, which makes protection measures unnecessary if the state of preservation in the wood does not provide enough nutrients for shipworms (Eriksen et al. 2015). 


\section{Research Activities on Marine Applications in Recent Years}

The protection of wood in the marine environment has traditionally been a research topic for The International Research Group on Wood Protection (IRG-WP). A joint meeting of IRG-WP and COIPM (Comité International Permanent pour la Recherche sur la Preservation des Materiaux en Milieu Marin) resulted in the Marine Working Group being a formal part of IRG-WP (Eaton 1977). Cragg (1986) gave a comprehensive review on marine biodeterioration at the IRG-WP conference in 1986, which included relevant papers from an international conference from the same year in India. An updated version of the different Limnoriidae can be found in the IRG-WP article of Cookson (1990). In addition to the research on individual wood borer species, the different stages of wood fragmentation by the different wood borers has been described (Nishimoto et al. 2015), as well as the rate of wood material consumption (Charles et al. 2018).

Many scientific publications from the last 20 years report mostly on the performance of well-known and established treatments of timber, either preservative or modification systems, and the different wood treatments or wood species tested in marine field sites in different parts of the world or in the laboratory. However, little is presented on the mode of action of either the protection systems or the biology of the different organisms of wood borers (Barnacle 1990), and only one paper discusses a novel wood treatment, based on mineralization, which is not described in detail by the authors (Bowen et al. 2017).

The authors believe that the research focus should be shifted towards finding out how, when, and why the different species of wood borers attack. The number of scientific papers on the topic in the last 20 years does not reflect the importance of the problem. In fact, the problem is urgent, as established effective treatments are no longer available for use in the marine environment in Europe.

Table 2. Permanent Marine Test Sites in Europe

\begin{tabular}{|c|c|c|c|}
\hline Test Site & Coordinates & Wood-boring Organisms & $\begin{array}{c}\text { Institution and } \\
\text { Reference Person }\end{array}$ \\
\hline $\begin{array}{l}\text { Kristineberg, } \\
\text { Sweden }\end{array}$ & $\begin{array}{l}58^{\circ} 15^{\prime} 00.3^{\prime \prime N} \\
11^{\circ} 26^{\prime} 42.9^{\prime \prime} \mathrm{E}\end{array}$ & Teredo navalis & RISE, Mats Westin \\
\hline Oslo, Norway & $\begin{array}{l}59^{\circ} 36^{\prime} 57.5^{\prime \prime N} \\
10^{\circ} 39^{\prime} 03.7 " \mathrm{E}\end{array}$ & Teredo navalis & $\begin{array}{l}\text { Norwegian Institute of } \\
\text { Bioeconomy Research } \\
\text { (NIBIO), Andreas Treu }\end{array}$ \\
\hline $\begin{array}{l}\text { Koper, } \\
\text { Slovenia }\end{array}$ & $\begin{array}{l}45^{\circ} 33^{\prime} 40.2^{\prime \prime} \mathrm{N} \\
13^{\circ} 44^{\prime} 21.0^{\prime \prime} \mathrm{E}\end{array}$ & Teredo navalis, Limnoria sp. & $\begin{array}{c}\text { University of Ljubliana, } \\
\text { Miha Humar }\end{array}$ \\
\hline $\begin{array}{l}\text { Hejlsminde, } \\
\text { Denmark }\end{array}$ & $\begin{array}{c}55^{\circ} 21^{\prime} 40.7^{\prime \prime N} \\
9^{\circ} 36^{\prime} 01.1 " \mathrm{E}\end{array}$ & Teredo navalis & $\begin{array}{c}\text { University of } \\
\text { Goettingen, Christian } \\
\text { Brischke }\end{array}$ \\
\hline $\begin{array}{l}\text { Olhão, } \\
\text { Portugal }\end{array}$ & $\begin{array}{r}37^{\circ} 01^{\prime} 37.2 " \mathrm{~N} \\
7^{\circ} 50^{\prime} 28.068 " \mathrm{~W}\end{array}$ & $\begin{array}{l}\text { Lyrodus pedicellatus, } \\
\text { Teredo bartschi, } \\
\text { Limnoria tripunctata }\end{array}$ & $\begin{array}{c}\text { Sagremarisco, } \\
\text { John Icely }\end{array}$ \\
\hline $\begin{array}{c}\text { Portsmouth, } \\
\text { UK }\end{array}$ & $\begin{array}{l}50^{\circ} 47^{\prime} 40.5 " \mathrm{~N} \\
1^{\circ} 01^{\prime} 48.1^{\prime \prime} \mathrm{W}\end{array}$ & $\begin{array}{c}\text { Limnoria quadripunctata, Lyrodus } \\
\text { pedicellatus, Teredo navalis, } \\
\text { Chelura terebrans }\end{array}$ & $\begin{array}{c}\text { University of } \\
\text { Portsmouth, Simon } \\
\text { Craga }\end{array}$ \\
\hline Italy & $\begin{array}{c}38^{\circ} 12^{\prime} 1.00^{\prime \prime} \mathrm{N} \\
15^{\circ} 33^{\prime} 52.00^{\prime \prime} \mathrm{E}\end{array}$ & Teredo navalis & (Palanti et al. 2015) \\
\hline
\end{tabular}

\section{Marine Test Sites in Europe}

Treu et al. (2019). "Timber in marine environments," BioResources 14(4), 10161-10184. 10174 
A comprehensive study has been performed on the distribution and abundance of different wood-boring species in Europe (Borges et al. 2014a, 2014b). However, the described locations were surveyed only for a limited period (one year) and in other cases, borers have been observed during ad hoc site inspections. Nonetheless, there are a few sites that have been monitored over a long-term period, thus providing important information on marine wood-boring organisms (Table 2 and Fig. 2). One example is the occurrence of wood borers in the Oslofjord in Norway (Treu et al. 2018), which has only been reported earlier by Jones et al. (1972).

Researchers in Sweden have been conducting tests in marine environments continually for over 15 years. Their field site in Kristineberg, Sweden has been used for many kinds of projects in the past (Westin et al. 2006, 2016). Different chemically modified wood has been tested at the Danish test site, Heijlsminde, during the last ten years (Gellerich et al. 2018). Knowledge of the distribution and occurrence of the various species of marine wood borers is essential. Therefore, new permanent test sites are needed where a testing regime can be in service and maintained over many years.

\section{CONCLUDING REMARKS}

This review on recent research activities on the protection and preservation of timber structures in the marine environment led the authors to the following conclusions.

Timber structures in the marine environment require protection against both biological organisms and mechanical forces. The use of timber in marine applications competes with the use of concrete and steel. In addition, no wood preservative is approved for marine applications in Europe. Viable alternatives to the banned wood preservation systems and some tropical wood species need to be found if timber wants to play a bigger role in marine applications. The requirements for not only efficacy against wood-degrading organisms, but also for no harmful side effects for non-target organisms must be met by new methods of wood protection.

Lesser known tropical wood species are difficult to market due to the lack of reliable test data on their performance, especially strength properties. More research on the properties of tropical wood species from sustainable forestry would contribute positively to the use of wood in marine structures.

Coastline protection is an increasing problem and will lead to higher costs in the future. Timber used for coastline protection needs to be fit for purpose in a harsh environment. Changes in salinity and temperature of seawater can lead to the spreading of wood-degrading organisms.

Research activities on the protection of timber structures for the marine environment in Europe have been scarce and do not yet adequately meet the need for novel approaches to the problem of biodeterioration of wood in the marine environment. Recent research on novel wood protection systems for seawater applications is shaped by the idea of preventing settlement on the wood surface or interfering with digestive processes. There is a need to understand more about how and why marine wood borers attack timber and focus more on the different species of degrading organisms and the mode of action. Permanent and temporary test sites would help to monitor species abundance and distribution and thus changes in borer hazards.

\section{REFERENCES CITED}

Treu et al. (2019). "Timber in marine environments," BioResources 14(4), 10161-10184. 10175 
Alexander, M. G., and G. Nganga (2016). "1 - Introduction: Importance of marine concrete structures and durability design," Marine Concrete Structures-Design, Durability and Performance. M. G. Alexander (ed.), Woodhead Publishing: 1-13.

American Wood Protection Association (AWPA) (2017). AWPA Book of Standards, American Wood Protection Association, Birmingham, USA.

Appelqvist, C. (2015). Shipworm Ecology in Swedish Coastal Waters, Doctoral Thesis, University of Gothenburg, Gothenburg, Sweden.

Appelqvist, C., Al-Hamdani, Z. K., Jonsson, P. R., and Havenhand, J. N. (2015). "Climate envelope modeling and dispersal simulations show little risk of range extension of the shipworm, Teredo navalis (L.), in the Baltic Sea," PloS One 10(3), e0119217. DOI: 10.1371/journal.pone.0119217

Appelqvist, C., Havenhand, J. N., and Toth, G. B. (2014). "Distribution and abundance of teredinid recruits along the Swedish coast - are shipworms invading the Baltic Sea?," Journal of the Marine Biological Association of the United Kingdom 95(4), 783-790. DOI: $10.1017 / \mathrm{S} 0025315414001830$

AS1604.1 (2012). "Specification for preservative treatment. Part 1: Sawn and round timber," Australian Standard, Sydney, Australia.

Barnacle, J. E. (1990). "Marine borers and marine wood protection - Some answers and some outstanding questions - A comment," in: The International Research Group on Wood Protection Conference, Rotorua, New Zealand, pp. 1-21.

Betcher, M. A., Fung, J. M., Han, A. W., O’Connor, R., Seronay, R., Concepcion, G. P., Distel, D. L., and Haygood, M. G. (2012). "Microbial distribution and abundance in the digestive system of five shipworm species (Bivalvia: Teredinidae)," PLoS One 7(9), e45309. DOI: 10.1371/journal.pone.0045309

Björdal, C. G., and Nilsson, T. (2008). "Reburial of shipwrecks in marine sediments: A long-term study on wood degradation," Journal of Archaeological Science 35(4), 862-872. DOI: 10.1016/j.jas.2007.06.005

Björdal, C. G., Nilsson, T., and Daniel, G. (1999). "Microbial decay of waterlogged archaeological wood found in Sweden applicable to archaeology and conservation," International Biodeterioration \& Biodegradation 43(1-2), 63-73. DOI: 10.1016/s0964-8305(98)00070-5

Blanchette, R. A. (2000). "A review of microbial deterioration found in archaeological wood from different environments," International Biodeterioration \& Biodegradation 46(3), 189-204. DOI: 10.1016/S0964-8305(00)00077-9

Board, P. A. (1970). "Some observations on the tunneling of shipworms," Journal of Zoology 161(2), 193-201. DOI: 10.1111/j.1469-7998.1970.tb02034.x

Borges, L. M. S., Cragg, S. M., Bergot, J., Williams, J. R., Shayler, B., and Sawyer, G. S. (2008). "Laboratory screening of tropical hardwoods for natural resistance to the marine borer Limnoria quadripunctata: The role of leachable and non-leachable factors," Holzforschung 62, 99-111. DOI: 10.1515/HF.2008.015

Borges, L. M. S., and Merckelbach, L. M. (2018). "Lyrodus mersinensis sp. nov. (Bivalvia: Teredinidae) another cryptic species in the Lyrodus pedicellatus (Quatrefages, 1849) complex," Zootaxa 4442(3), 441-457. DOI: 10.11646/zootaxa.4442.3.6

Borges, L. M. S., Merckelbach, L. M., and Cragg, S. M. (2014a). "Biogeography of wood-boring crustaceans (Isopoda: Limnoriidae) established in European coastal waters," PLoS One 9(10), e109593. DOI: 10.1371/journal.pone.0109593

Treu et al. (2019). "Timber in marine environments," BioResources 14(4), 10161-10184. 10176 
Borges, L. M. S., Merckelbach, L. M., Sampaio, Í., and Cragg, S. M. (2014b). "Diversity, environmental requirements, and biogeography of bivalve wood borers (Teredinidae) in European coastal waters," Frontiers in Zoology 11(1), 1-13. DOI: 10.1186/17429994-11-13

Borges, L. M. S., Sivrikaya, H., and Cragg, S. M. (2014c). "First records of the warm water shipworm Teredo bartschi Clapp, 1923 (Bivalvia, Teredinidae) in Mersin, southern Turkey and in Olhao, Portugal," Bioinvasions Records 3(1), 25-28. DOI: 10.3391/bir.2014.3.1.04

Bowen, H., Montibus, M., Kutnik, M., and Cragg, S. M. (2017). "Novel wood treatments improve resistance to the wood-boring marine isopod Limnoria quadripunctata," in:

The International Research Group on Wood Protection Conference, Ghent, Belgium, pp. 1-12.

Charles, F. K., Coston-Guarini, J., Guarini, J. -M., and Lantoine, F. (2018). "It's what's inside that counts: Computer-aided tomography for evaluating the rate and extent of wood consumption by shipworms," Journal of Wood Science 64(4), 427-435. DOI: 10.1007/s10086-018-1716-x

Christensen, M., Frosch, M., Jensen, P., Schnell, U., Shashoua, Y., and Nielsen, O. F. (2006). "Waterlogged archaeological wood-chemical changes by conservation and degradation," Journal of Raman Spectroscopy 37(10), 1171-1178. DOI: $10.1002 /$ jrs. 1589

Cookson, L. J. (1990). "Annotated check-list of the Limnoriidae," in: The International Research Group on Wood Protection Conference, Rotorua, New Zealand, pp. 1-15.

Cragg, S. M. (1986). "Report on International Conference on Marine Biodeterioration, Goa, India, January 1986," in: The International Research Group on Wood Protection Conference, Avignon, France, pp. 1-12.

Cragg, S. M. (1996). "Timber in the marine environment," Timber Trades Journal 376, 26-28

Cragg, S. M. (2003). "Marine wood-boring arthropods: Ecology, functional anatomy, and control measures," in: Wood Deterioration and Preservation, American Chemical Society, Washington DC, USA, pp. 272-286. DOI: 10.1021/bk-2003-0845.ch015

Cragg, S. M., Danjon, C., and Mansfield-Williams, H. (2007). "Contribution of hardness to the natural resistance of a range of wood species to attack by the marine borer Limnoria," Holzforschung 61(2), 201-206. DOI: 10.1515/HF.2007.035

Crossman, M. and J. Simm (2004). Manual on the Use of Timber in Coastal and River Engineering, Thomas Telford Ltd.

Daniel, G., and T. Nilsson (1998). "Developments in the study of soft rot and bacterial decay," in: Forest Products Biotechnology, pp. 37-63, Taylor and Francis Ltd.

Distel, D. L. (2003). "The biology of marine wood-boring bivalves and their bacterial endosymbionts," in: Wood Deterioration and Preservation, American Chemical Society, Washington DC, USA, pp. 253-271. DOI: 10.1021/bk-2003-0845.ch014

Distel, D. L., Beaudoin, D. J., and Morrill, W. (2002). "Coexistence of multiple proteobacterial endosymbionts in the gills of the wood-boring Bivalve Lyrodus pedicellatus (Bivalvia: Teredinidae)," Applied and Environmental Microbiology 68(12), 6292-6299. DOI: 10.1128/AEM.68.12.6292-6299.2002

Dons, C. (1948). "Marine boreorganismer. XIII. Teredo- Produksjonen og sjøtemperaturen [Teredo- Production and sea water temperature]," Det Kongelige Norske Videnskabers Selskap, Forhandlinger XXI [Royal Norwegian Society of Sciences and Letters, Communications] 21(42), 186-190.

Treu et al. (2019). "Timber in marine environments," BioResources 14(4), 10161-10184. 10177 
Dorgan, K. M. (2015). "The biomechanics of burrowing and boring," Journal of Experimental Biology 218(2), 176-183. DOI: 10.1242/jeb.086983

Eaton, R. A. (1977). "Status of the working group on preservation of wood in the marine environment - Questionnaire results," in: The International Research Group on Wood Protection Conference, Noordwijk aan Zee, The Netherlands, pp. 1.

Elshahawi, S. I., Trindade-Silva, A. E., Hanora, A., Han, A. W., Flores, M. S., Vizzoni, V., Schrago, C. G., Soares, C. A., Concepcion, G. P., Distel, D. L., et al. (2013).

"Boronated tartrolon antibiotic produced by symbiotic cellulose-degrading bacteria in shipworm gills," Proceedings of the National Academy of Sciences of the United States of America 110(4), 295-304. DOI: 10.1073/pnas.1213892110

EN 335 (2013). "Durability of wood and wood-based products use classes: Definitions, application to solid wood and wood-based products," European Committee for Standardization, Brussels, Belgium.

EN 350 (2016). "Durability of wood and wood-based products testing and classification of the durability to biological agents of wood and wood-based materials," European Committee for Standardization, Brussels, Belgium.

Environmental Agency (2018). "NGSA - Marine and coastal works framework Environment Agency," Government Tenders, Government News and Information, Government of the United Kingdom, London, UK.

European Environment Agency (2016). Coastline dynamics in Europe, https://www.eea.europa.eu/data-and-maps/figures/coastal-erosion-patterns-in-europe1 , viewed at 02.10.2019

Eriksen, A. M., Gregory, D., and Shashoua, Y. (2015). "Selective attack of waterlogged archaeological wood by the shipworm, Teredo navalis and its implications for in situ preservation," Journal of Archaeological Science 55, 9-15. DOI:

10.1016/j.jas.2014.12.011

European Union (EU) Regulation 305/2011 (2011). "Regulation (EU) No 305/2011 of the European Parliament and of the Council of 9 March 2011 laying down harmonised conditions for the marketing of construction products and repealing Council Directive 89/106/EEC," European Parliament and the Council of the European Union, Brussels, Belgium.

EU Regulation 528/2012 (2012). "Regulation (EU) No 528/2012 of the European parliament and of the council of 22 May 2012 concerning the making available on the market and use of biocidal products," European Parliament and the Council of the European Union, Brussels, Belgium.

Eurosion (2002). Coastal Erosion Indicators Study-Coastal Erosion - Evaluation of the needs for action (Contract No.: B4-3301/2001/329175/MAR/B3), Universitat Autonoma de Barcelona, Bellaterra, Spain.

Findlay, G. (2013). Preservation of Timber in the Tropics, Springer Netherlands, New York City, USA. DOI: 10.1007/978-94-017-2752-5

Fors, Y., and Sandström, M. (2006). "Sulfur and iron in shipwrecks cause conservation concerns," Chemical Society Reviews 35(5), 399-415. DOI: 10.1039/B507010B

Gellerich, A., Brischke, C., Militz, H., and Klüppel, A. (2018). "Resistance of modified wood against marine borers," Holztechnologie 59(4), 5-11.

Hanson, H., Brampton, A., Capobianco, M., Dette, H. H., Hamm, L., Laustrup, C., Lechuga, A., and Spanhoff, R. (2002). "Beach nourishment projects, practices, and objectives- a European overview," Coastal Engineering 47(2), 81-111. DOI: 10.1016/S0378-3839(02)00122-9 
Hellkamp, S. (2012). "Holz im Meerwasserverbau - Schädlinge im Meerwasser, Teredo ssp. und Limnoria ssp. Lebenszyklus, schadbilder und auswirkungen auf holzkonstruktionen [Wood in marine structures - Fouling organisms in sea water, Teredo ssp. And Limnoria ssp. Live cycle, attack pattern, and consequences for wood structures]," Deutsche Holzschutztagung [German Wood Protection Symposium], Cuvillier, Göttingen, Germany, pp. 46-51.

Hoagland, K. E. (1986). "Effects of temperature, salinity, and substratum on larvae of the shipworms Teredo bartschi Clapp and Teredo navalis Linnaeus (Bivalvia, Teredinidae) American Malacological Bulletin 4:89-99

Hoffmann, P. (2001). "To be and to continue being a cog: The conservation of the Bremen Cog of 1380," International Journal of Nautical Archaeology 30(1), 129140. DOI: 10.1111/j.1095-9270.2001.tb01364.x

Hudson, T., Keating, K., and Pettit, A. (2015). Cost Estimation for Coastal Protection Summary of Evidence (Report No. SC080039/R7), Environment Agency, Bristol, England.

Humar, M., Petric, M., Adamek, J., and Lesar, B. (2013). "Performance of untreated wood and wood impregnated with copper-ethanolamine based preservative solutions in Northern Adriatic Sea," in: The International Research Group on Wood Protection Conference, Stockholm, Sweden, pp. 1-11.

Hyde, K. D., Jones, E. B. G., Leaño, E., Pointing, S. B., Poonyth, A. D., and Vrijmoed, L. L. P. (1998). "Role of fungi in marine ecosystems," Biodiversity \& Conservation 7(9), 1147-1161. DOI: 10.1023/A:1008823515157

Iljin, I. N. (2010). "Known and possible invasions of marine mollusks of the families Teredinidae and Pholadidae (Bivalvia) in the waters of Russia and adjacent countries," Russian Journal of Biological Invasions 1(2), 74-80. DOI: $10.1134 / \mathrm{S} 2075111710020049$

Janus, M., Cragg, S., Brischke, C., Meyer-Veltrup, L., and Wehsener, J. (2018). "Laboratory screening of thermo-mechanically densified and thermally modified timbers for resistance to the marine borer Limnoria quadripunctata," European Journal of Wood and Wood Products 76(1), 393-396. DOI: 10.1007/s00107-0171239-y

Jones, E. B. G., Kühne, H., Trussell, P. C., and Turner, R. D. (1972). "Results of an international cooperative research programme on the biodeterioration of timber submerged in the sea," Material und Organismen 7(2), 93-118.

Jonker, J. -L., Morrison, L., Lynch, E. P., Grunwald, I., Von Byern, J., and Power, A. M. (2015). "The chemistry of stalked barnacle adhesive (Lepas anatifera)," Interface Focus 5(1), DOI: 10.1098/rsfs.2014.0062

Kern, M., McGeehan, J. E., Streeter, S. D., Martin, R. N., Besser, K., Elias, L., Eborall, W., Malyon, G. P., Payne, C. M., and Himmel, M. E. (2013). "Structural characterization of a unique marine animal family 7 cellobiohydrolase suggests a mechanism of cellulase salt tolerance," Proceedings of the National Academy of Sciences 110(25), 10189-10194. DOI: 10.1073/pnas.1301502110

King, A. J., Cragg, S. M., Li, Y., Dymond, J., Guille, M. J., Bowles, D. J., Bruce, N. C., Graham, I. A., and McQueen-Mason, S. J. (2010). "Molecular insight into lignocellulose digestion by a marine isopod in the absence of gut microbes," Proceedings of the National Academy of Sciences 107(12), 5345-5350. DOI: 10.1073/pnas.0914228107 
Klüppel, A. (2018). Untersuchungen zur Dauerhaftigkeit von kunstharz-modifiziertem Holz bei Verwendung in Meerwasserkontakt [Investigations on the Durability of Resin-modified Wood in Marine Contact], Ph.D. Thesis, Georg-August University, Göttingen, Germany.

Klüppel, A., Mai, C., Militz, H., and Cragg, S. M. (2014). "Performance of some wood modification treatments against marine borers," in: The International Research Group on Wood Protection Conference, St. George, USA, pp. 1-10.

Knudsen, J. (1961). "The bathyal and abyssal Xylophaga (Pholadidae, Bivalvia)," in: Galathea Report: Scientific Results of the Danish Deep-Sea Expedition Round the World 1950-52, Volume 5, A. F. Bruun (ed.), Danish Science Press, Copenhagen, Denmark, pp. 163-209.

Knudsen, P. (1974). Pelemark - Marin Treborer (Report No. QS1978/40) [ShipwormMarine Borers (Report No. QS1978/40)], Norsk Institutt for Skogforskning [Norwegian Forest Research Institute], Ås, Norway.

Kutnik, M., Klamer, M., and Melcher, E. (2017). "Ensuring quality of treated wood regulations, certifications and associative background in the field of wood protection in Europe," in: Proceedings of the International Research Group on Wood Protection Annual Meeting, Ghent, Belgium, pp. 1-15.

Leatherman, S. P., Zhang, K., and Douglas, B. C. (2000). "Sea level rise shown to drive coastal erosion," Eos, Transactions American Geophysical Union 81(6), 55-57. DOI: 10.1029/00EO00034

Lincke, D., and Hinkel, J. (2018). "Economically robust protection against $21^{\text {st }}$ century sea-level rise," Global Environmental Change 51, 67-73. DOI: 10.1016/j.gloenvcha.2018.05.003

Lindfors, E. L., Lindstrom, M., and Iversen, T. (2008). "Polysaccharide degradation in waterlogged oak wood from the ancient warship Vasa," Holzforschung 62(1), 57-63. DOI: $10.1515 / \mathrm{hf} .2008 .008$

Lippert, H., Weigelt, R., Glaser, K., Krauss, R., Bastrop, R., and Karsten, U. (2017). "Teredo navalis in the Baltic Sea: Larval dynamics of an invasive wood-boring bivalve at the edge of its distribution," Frontiers in Marine Science 4(331), 1-12. DOI: 10.3389/fmars.2017.00331

Lopez-Anido, R., Michael, A. P., and Sandford, T. C. (2003). "Experimental characterization of FRP composite-wood pile structural response by bending tests," Marine Structures 16(4), 257-274. DOI: 10.1016/S0951-8339(03)00021-2

Lopes, D. B., Mai, C., Militz, H. (2014). "Marine borers resistance of chemically modified Portuguese wood," Maderas-Ciencia y Tecnologia 16(1), 109-124.

Magin, C. M., Cooper, S. P., and Brennan, A. B. (2010). "Non-toxic antifouling strategies," Materials Today 13(4), 36-44. DOI: 10.1016/S1369-7021(10)70058-4

Masters, N. (2001). Sustainable Use of New and Recycled Materials in Coastal and Fluvial Construction - A Guidance Manual, Thomas Telford, London

Menzies, R. J. (1957). "The marine borer family Limnoriidae (Crustacea, Isopoda). Part I: Northern and Central America: Systematics, distribution, and ecology," Bulletin of Marine Science of the Gulf and Caribbean 7(2), 101-200.

Merk, V., Berg, J. K., Krywka, C., and Burgert, I. (2017). "Oriented crystallization of barium sulfate confined in hierarchical cellular structures," Crystal Growth and Design 17(2), 677-684. DOI: 10.1021/acs.cgd.6b01517 
Merk, V., Chanana, M., Gaan, S., and Burgert, I. (2016). "Mineralization of wood by calcium carbonate insertion for improved flame retardancy," Holzforschung 70(9), 867-876. DOI: $10.1515 / \mathrm{hf}-2015-0228$

Merk, V., Chanana, M., Keplinger, T., Gaan, S., and Burgert, I. (2015). "Hybrid wood materials with improved fire retardance by bio-inspired mineralisation on the nanoand submicron level," Green Chemistry 17(3), 1423-1428. DOI:

10.1039/C4GC01862A

Miller, R. C. (1924). The Boring Mechanism of Teredo, University of California Press, Berkeley, CA, USA.

Mouzouras, R., Jones, A. M., Jones, E., and Rule, M. H. (1990). "Non-destructive evaluation of hull and stored timbers from the Tudor ship Mary Rose," Studies in Conservation 35(4), 173-188. DOI: 10.2307/1506410

Müller, J. (2014). Praxisnahe Untersuchungen zur Wirksamkeit von Geotextilien gegen Holzschädlinge im Meerwasser (Report No. AZ 30193) [Practical Investigations on the Effectiveness of Geotextiles Against Wood Borers in Seawater (Report No. AZ 30193)], Deutsche Bundesstiftung Umwelt (DBU) [German Federal Environmental Foundation], Dörpen, Germany.

Nair, N. B. (1962). "Ecology of marine fouling and wood-boring organisms of Western Norway," Sarsia 8(1), 1-88. DOI: 10.1080/00364827.1962.10410269

Nerem, R. S., Beckley, B. D., Fasullo, J. T., Hamlington, B. D., Masters, D., and Mitchum, G. T. (2018). "Climate-change-driven accelerated sea-level rise detected in the altimeter era," Proceedings of the National Academy of Sciences of the United States of America 114(9), 2022-2025. DOI: 10.1073/pnas.1717312115

Nishimoto, A., Haga, T., Asakura, A., and Shirayama, Y. (2015). "An experimental approach for understanding the process of wood fragmentation by marine wood borers in shallow temperate waters." Marine Ecology Progress Series 538: 53-65.

Norman, E. (1976). "Natural resistance of different species of Swedish timbers to attack by marine wood-boring molluscs," Institutionen for Virkeslåra Rapporter 98, 1-14.

O'Connor, R. M., Fung, J. M., Sharp, K. H., Benner, J. S., McClung, C., Cushing, S., Lamkin, E. R., Fomenkov, A. I., Henrissat, B., Londer, Y. Y., et al. (2014). "Gill bacteria enable a novel digestive strategy in a wood-feeding mollusk," Proceedings of the National Academy of Sciences of the United States of America 111(47), 50965104. DOI: 10.1073/pnas.1413110111

Oevering, P., Matthews, B. J., Cragg, S. M., and Pitman, A. J. (2001). "Invertebrate biodeterioration of marine timbers above mean sea level along the coastlines of England and Wales," International Biodeterioration \& Biodegradation 47(3), 175 181. DOI: 10.1016/S0964-8305(01)00046-4

Palanti, S., Feci, E., and Anichini, M. (2015). "Comparison between four tropical wood species for their resistance to marine borers (Teredo spp and Limnoria spp) in the Strait of Messina," International Biodeterioration \& Biodegradation 104, 472-476. DOI: 10.1016/j.ibiod.2015.07.013

Parkes, L., and Keeble, A. (2016). "The Teredo worm and subsea umbilicals: Risks and recommendations," Underwater Technology 33(4), 239-243. DOI: 10.3723/ut.33.239

Purchon, R. D. (1941). "On the biology and relationships of the lamellibranch Xylophaga dorsalis (Turton)," Journal of the Marine Biological Association of the United Kingdom 25(1), 1-39.

Roder, H. (1977). "Zur Beziehung zwischen Konstruktion und Substrat bei mechanisch bohrenden Bohrmuscheln (Pholadidae, Teredinidae) [On the relationship between 
construction and substrate in mechanical drilling borers (Pholadidae, Teredinidae)]," Senckenbergiana Maritima 9, 105-213.

Rosenbusch, K., Borges, L. M. S., Cragg, S. M., Rapp, A. O., and Pitman, A. J. (2006).

"A laboratory assessment of the natural durability of the lesser-utilised species Corynanthe pachyceras Welw. and Glyphaea brevis (Sprengel) Monachino against the marine wood borer Limnoria quadripunctata Holthius," International Biodeterioration \& Biodegradation 57(2), 71-74. DOI: 10.1016/j.ibiod.2005.11.005

Saathoff, F., Spittel, M., Dede, C., and Hinkerohe, C. (2010). Entwicklung Eines Verfahrens zum Schutz von Holzpfählen Gegen Teredo navalis - Zwischenbericht (Report No. AZ 26280/23) [Method Development to Protect Wooden Posts Against Teredo navalis- Preliminary Report (Report No. AZ 26280/23), Deutsche Bundesstiftung Umwelt (DBU) [German Federal Environmental Foundation], University Rostock, Osnabrück, Germany.

Sabbadin, F., Pesante, G., Elias, L., Besser, K., Li, Y., Steele-King, C., Stark, M., Rathbone, D. A., Dowle, A. A., Bates, R., et al. (2018). "Uncovering the molecular mechanisms of lignocellulose digestion in shipworms," Biotechnology for Biofuels 11(59), 1-18. DOI: 10.1186/s13068-018-1058-3

Salman, A., Lombardo, S., and Doody, P. (2004). Living With Coastal Erosion in Europe: Sediment and Space for Sustainability. Part I - Major Findings and Policy Recommendations of the EUROSION Project (Service contract B43301/2001/329175/MAR/B3), Directorate General Environment - European Commission, The Hague, Netherlands.

Sandström, M., Fors, Y., and Persson, I. (2003). The Vasa's New Battle: Sulfur, Acid and Iron, National Maritime Museums [Statens maritima museer], Stockholm, Sweden.

Sandström, M., Jalilehvand, F., Damian, E., Fors, Y., Gelius, U., Jones, M., and Salome, M. (2005). "Sulfur accumulation in the timbers of King Henry VIII's warship Mary Rose: A pathway in the sulfur cycle of conservation concern," Proceedings of the National Academy of Sciences of the United States of America 102(40), 14165-14170. DOI: 10.1073/pnas.0504490102

South African National Standard (SANS) 10005 (2016). "The preservative treatment of timber," SABS Standards Division, Pretoria, South Africa.

Santhakumaran, L. N., and Sneli, J. A. (1978). "Natural resistance of different species of timber to marine borer attack in the Trondheimsfjord (Western Norway)," in: The International Research Group on Wood Protection Scientific Conference, Peebles, Scotland, UK, pp. 1-20.

Santhakumaran, L. N., and Sneli, J. A. (1984). "Studies on the marine fouling and woodboring organisms of the Trondheimsfjord (Western Norway)," Gunneria 48, 136.

Sen, S., Sivrikaya, H., Yalcin, M. (2009). "Natural durability of heartwoods from European and tropical Africa trees exposed to marine conditions," African Journal of Biotechnology 8(18), 4425-4432.

Serpa, F. d. G. (1980). "Laboratory tests on wood impregnated with sodium silicate against the attack of Limnoria tripunctata menzies," Floresta 11(2), 42-44.

Shipway, J. R., Borges, L. M. S., Muller, J., and Cragg, S. M. (2014). "The broadcast spawning Caribbean shipworm, Teredothyra dominicensis (Bivalvia, Teredinidae), has invaded and become established in the eastern Mediterranean Sea," Biological Invasions 16(10), 2037-2048. DOI: 10.1007/s10530-014-0646-9

Treu et al. (2019). "Timber in marine environments," BioResources 14(4), 10161-10184. 10182 
Simm, J., and Masters, N. (2003). Whole Life Costs and Project Procurement in Port, Coastal and Fluvial Engineering: How to Escape the Cost Boxes, ICE Publishing, Thomas Telford, Ltd., London, United Kingdom.

Simpson, M. J. R., Nilsen, J. E. Ø., Ravndal, O. R., Breili, K., Sande, H., Kierulf, H. P., Steffen, H., Jansen, E., Carson, M., and Vestøl, O. (2015). Sea Level Change for Norway - Past and Present Observations and Projections to 2100 (Report No. 1/2015), Norwegian Centre for Climate Services, Oslo, Norway.

Sordyl, H., Bönsch, R., Gercken, J., Gosselck, F., Kreuzber, M., and Schulze, H. (1998). "Verbreitung und Reproduktion des Schiffsbohrwurms Teredo navalis L. an der Küste Mecklenburg-Vorpommerns [Distribution and reproduction of the marine shipworm Teredo navalis L. on the coast of Mecklenburg-West Pomerania]," Deutsche Gesellschaft für Meeresforschung [The German Society of Marine Research] 42, 142-149.

Sosa, M., Perez-Lopez, T., Reyes, J., Corvo, F., Camacho-Chab, R., Quintana, P., Aguilar, D. (2011). "Influence of the marine environment on reinforced concrete degradation depending on exposure conditions," International Journal of Electrochemical Science 6, 6300-6318.

Squirrell, J., and Clarke, R. (1987). "An investigation into the condition and conservation of the hull of the Mary Rose. Part I: Assessment of the hull timbers," Studies in Conservation 32(4), 153-162. DOI: 10.2307/1506179

State Agency for Agriculture and Environment Middle Mecklenburg (2017). "Buhnenbau im Küstenschutz von Mecklenburg-Vorpommern [Groyne building in coastal protection of Mecklenburg-West Pomerania]," Staatliches Amt für Landwirtschaft und Umwelt Mittleres Mecklenburg, (http://www.stalumv.de/mm/Themen/K\%C3\%BCstenschutz/Buhnenbau-im-K\%C3\%BCstenschutzvon-Mecklenburg\%E2\%80\%93Vorpommern/), Accessed 8 Jan 2019.

Stephan, I., Kutnik, M., Conti, E., Klamer, M., Nunes, L., Acker, J. V., and Plarre, R. (2017). "Guidance on the European biocidal products regulation concerning efficacy of wood preservatives," in: Proceedings of the $48^{\text {th }}$ IRG Annual Meeting, Ghent, Belgium, pp. 1-16.

Toth, G. B., Larsson, A. I., Jonsson, P. R., and Appelqvist, C. (2015). "Natural populations of shipworm larvae are attracted to wood by waterborne chemical cues," PLoS One 10(5), e0124950. DOI: 10.1371/journal.pone.0124950

Treu, A., Zimmer, K., Brischke, C., Larnøy, E., Gobakken, L. R., Aloui, F., Cragg, S. M., Flæte, P. O., Humar, M., and Westin, M. (2018). "Hibernation or spring awakening? The research on wood durability and protection in marine environment," in: The IRG 49 Scientific Conference on Wood Protection, Sandton, South Africa, pp. 1-19.

Tsinker, G. P. (1995). "The dock-in-service: Evaluation of load carrying capacity, repair, rehabilitation," Marine Structures Engineering: Specialized Applications, Springer US, Boston, USA, pp. 1-104. DOI: 10.1007/978-1-4615-2081-8

Tuente, U., Piepenburg, D., and Spindler, M. (2002). "Occurrence and settlement of the common shipworm Teredo navalis (Bivalvia: Teredinidae) in Bremerhaven harbours, northern Germany," Helgoland Marine Research 56(2), 87-94. DOI: 10.1007/s10152002-0101-7

Turner, R. D. (1966). A Survey and Illustrated Catalogue of the Teredinidae (Mollusca: Bivalvia), Museum of Comparative Zoology, Cambridge, MA, USA. DOI:

10.5962/bhl.title.67017

Treu et al. (2019). "Timber in marine environments," BioResources 14(4), 10161-10184. 10183 
Voight, J. R. (2015). "Xylotrophic bivalves: Aspects of their biology and the impacts of humans," Journal of Molluscan Studies 81(2), 175-186. DOI: 10.1093/mollus/eyv008

Wassnig, M., and Southgate, P. C. (2012). "Effects of settlement cues on behaviour and substrate attachment of hatchery reared winged pearl oyster (Pteria penguin) larvae," Aquaculture 344-349, 216-222. DOI: 10.1016/j.aquaculture.2012.03.020

Westin, M., Larsson-Brelid, P., Nilsson, T., Rapp, A. O., Dickerson, J. P., Lande, S., and Cragg, S. M. (2016). "Marine borer resistance of acetylated and furfurylated wood results from up to 16 years of field exposure," in: Proceedings of the $47^{\text {th }}$ IRG Annual Meeting, Lisbon, Portugal, pp. 1-9.

Westin, M., Rapp, A., and Nilsson, T. (2006). "Field test of resistance of modified wood to marine borers," Wood Material Science and Engineering 1(1), 34-38. DOI: $10.1080 / 17480270600686978$

Wiegemann, M. (2005). "Adhesion in blue mussels (Mytilus edulis) and barnacles (genus Balanus): Mechanisms and technical applications," Aquatic Sciences 67(2), 166-176. DOI: $10.1007 / \mathrm{s} 00027-005-0758-5$

Wiegemann, M., Kowalik, T., and Hartwig, A. (2006). "Noncovalent bonds are key mechanisms for the cohesion of barnacle (Balanus crenatus) adhesive proteins," Marine Biology 149(2), 241-246. DOI: 10.1007/s00227-005-0219-7

Wiegemann, M., and Watermann, B. (2004). "The impact of desiccation on the adhesion of barnacles attached to non-stick coatings," Biofouling 20(3), 147-153. DOI: 10.1080/08927010400001147

Wilkinson, J. G. (1979). Industrial Timber Preservation, Associated Business Press, London, UK.

Williams, J. R., Sawyer, G. S., Cragg, S. M., and Simm, J. (2005). "A questionnaire survey to establish the perceptions of UK specifiers concerning the key material attributes of timer for use in marine and fresh water engineering," Journal of the Institute of Wood Science 17(1), 41-50. DOI: 10.1179/wsc.2005.17.1.41

Article submitted: November 16, 2018; Peer review completed: March 17, 2019; Revised version received: October 2, 2019; Accepted: October 4, 2019; Published: October 11, 2019.

DOI: 10.15376/biores.14.4.Treu 